\title{
FAKTOR-FAKTOR YANG BERHUBUNGAN DENGAN KEPEMILIKAN JAMBAN KELUARGA
}

\section{Sri Lestari*}

\begin{abstract}
ABSTRAK
Jamban keluarga (JAGA) merupakan sarana sanitasi dasar untuk menjaga kesehatan lingkungan dalam rangka meningkatkan derajat kesehatan masyarakat. Desa leuwikidang adalah salah satu desa yang berada di Wilayah Kerja UPTD Puskesmas Kasokandel, salah satu permasalahan yang ada di desa ini yaitu rendah nya cakupan jamban keluarga dari 1,214 rumah baru sekitar 419 rumah atau 34,39\%, yang tidak memiliki jamban kebanyakan masih ke sungai dan ke kebun, hal ini masih di bawah target nasional mencapai $80 \%$, dengan kondisi demikian perlu dilakukan berbagai upaya masyarakat memiliki jamban keluarga yang memenuhi kesehatan. Tujuan penelitian ini adalah ingin mengetahui faktor lingkungan fisik dan sosial ekonomi apa saja yang dapat mempengaruhi kepemilikan jamban keluarga. Penelitian ini adalah analitik dari penelitian potong lintang atau cross sectional. Penelitian ini di lakukan dengan observasi dan wawancara kepada keluarga. Populasi penelitian ini dari seluruh rumah yang ada di desa Leuwikidang. Tekni sampel dengan menggunakan random sampling, dengan besar sampel 92 rumah. Variabel bebas pendidikan, pekerjaan, pendapatan, sarana air bersi, kepemilikan lahan, dan variabel terikat yaitu kepemilikan jamban keluarga. Hasil penelitian di peroleh hasi uji chi squar bahwa ada hubungan yang signifikan antara pendidikan ( $\mathrm{p}$ value $=0,048$ ) dengan kepemilikan jamban keluarga.
\end{abstract}

Kata kunci : Kepemilikan Jamban Keluarga

\section{ABSTRACT}

Family latrines (KEEP) is the basic sanitation facilities to maintain a healthy environment in order to improve the health of society. Leuwikidang village is one of the villages in the Work Area UPTD Kasokandel Health Center, one of the problems that exist in this village is its low latrine coverage of 1,214 families a new home approximately 419 homes, or $34.39 \%$, which does not have latrines mostly still to river and into the garden, it is still below the national target of reaching $80 \%$, with this condition need to be done a variety of community efforts have latrines that meet the family's health. The purpose of this study was to determine the physical environmental factors and socioeconomic anything that can affect families in the village latrine ownership Leuwikidang in Puskesmas Kasokandel. This study was a cross-sectional analytical research or cross-sectional. This study was done by observation and interviews with family. This study population of all the houses in the village Leuwikidang Majalengka.Teknic District Subdistrict Leukidang sample using random sampling, with a large sample of 92 rumah.Variabel free education, employment, income, clea water facilities, land ownership, and the dependent variable is the ownership of latrine family. Research results obtained hasi chi squar that there is a significant relationship between education ( $\mathrm{p}$ value $=0.048)$ with family latrine ownership.

Keywords: Family Latrine Ownership 


\section{PENDAHULUAN}

Berdasarkan target MDGs tersebut, Indonesia menghadapi dua tantangan. Pertama, Indonesia dihadapkan pada tantangan untuk meningkatkan hingga $67 \%$ proporsi penduduk yang memiliki akses terhadap sumber air minum yang aman. Kedua, Indonesia dihadapkan pada tantangan untuk meningkatkan hingga $69,3 \%$ proporsi penduduk yang memiliki akses terhadap fasilitas sanitasi dasar. Sumber air terlindung serta air perpipaan, sementara fasilitas sanitasi dasar terdiri dari jamban dengan tangki septik yang menandai. ${ }^{1}$

Saat ini, Indonesia telah mencapai angka $52,1 \%$ proporsi penduduk yang memiliki akses terhadap sumber air minum yang aman. Sementara untuk akses terhadap fasilitas sanitasi dasar, Indonesia telah melampaui target dengan mencapai angka 69,3\% penduduk telah memiliki akses terhadap fasilitas sanitasi dasar. Namun, kualitas dari fasilitas sanitasi dasar terbukti tidak di perhatikan dalam rangka angka pencapaiannya. ${ }^{2}$

Masyarakat terpaksa mengusahakan sendiri sanitasinya.Yaitu, dengan membuat tangki septik di bawah tanah dan cubluk. Yang lebih parah, mereka membuang ke sungai, bahkan yang lebih primitif lagi ditimbun ke dalam tanah begitu saja, padahal dampak dari praktik sanitasi yang buruk ini sangatlah besar. Bakteri Eschericia coli (E-coli) yang muncul dari sisa-sisa tinja yang terserap di tanah dapat mencemari sumber-sumber air minum. Pembuangan tinja perlu mendapat perhatian khusus karena merupakan satu bahan buangan yang banyak mendatangkan masalah dalam bidang kesehatan dan sebagai media bibit penyakit, seperti diare, typhus, muntaber, disentri, cacingan dan gatal-gatal. ${ }^{2}$

Masalah penyehatan lingkungan pemukiman khususnya pada pembuangan tinja merupakan salah satu dari berbagai masalah kesehatan yang perlu mendapatkan prioritas. Penyediaan sarana pembuangan tinja masyarakat terutama dalam pelaksanaannya tidaklah mudah, karena menyangkut peran serta masyarakat yang biasanya sangat erat kaitannya dengan lingkungan fisik seperti ketersediaan sarana air bersih merupakan analisis faktor risiko pada sarana air bersih dengan melakukan inpeksi dan menganalisa tingkat pencemaran untuk mengetahui kualitas air bersih yang tersedia memenuhi syarat kesehatan atau tidak dan sampai sejauh mana tingkat risiko pencemaran terhadap sumber air tersebut, dari seluruh sarana air bersih yang ada 11,062 sebesar 27,64\% (3057) yang telah dilakukan inpeksi sanitasi dari target $80 \%$ hasil inpeksi tersebut berdasarkan kriteria (kekeruhan,warna, rasa, bau) dan kriteria pencemaran yang memenuhi syarat sebesar $71,21 \%(2,177)$ yang mempunyai syarat tinggi dan proporsi kualitas air. Kepemilikan lahan, kepemilikan lahan yaitu untuk mengetahui kriteria rumah tersebut sudah memenuhi syarat rumah sehat di antara nya mengetahui apakah memiliki lahan yang tersedia untuk memungkinkan dapat membangun jamban untuk membangun jamban serta tingkat ekonomi masyarakat, diantaranya besarya pendapatan, golongan pekerjaan tetap dan tingkat pendidikan kepala keluarga, hal ini dapat mempengaruhi kepemilikan jamban dengan menganalisa dengan hasil pendapatan, dan sudah mampu atau tidak untuk membangun jamban keluarga. ${ }^{3}$

Tujuan program jamban keluarga (JAGA) yaitu tidak membuang tinja di tempat terbuka melainkan membangun jamban untuk diri sendiri dan keluarga. Penggunaan jamban yang baik adalah kotoran yang masuk hendaknya disiram dengan air yang cukup, hal ini selalu dikerjakan sehabis buang tinja sehingga kotoran tidak tampak lagi. Bagi rumah yang belum memiliki jamban, sudah dipastikan mereka itu memanfaatkan sungai, kebun, kolam, atau tempat lainnya untuk buang air besar (BAB) ${ }^{3}$

BAB di jamban banyak penyakit berbasis lingkungan yang dapat dicegah, tentunya jamban yang memenuhi syarat kesehatan. Kalau membahas soal jamban maka tentunya harus lengkap dengan sarana air bersih untuk menunjang keberlangsungan pemanfaatan jamban. Kondisi perekonomian masyarakat menentukan kualitas makanan, hunian kepadatan, gizi, 
tingkat pendidikan, tersedianya sarana air bersih, jamban keluarga, sanitasi kesehatan lainnya, besar kecilnya keluarga, teknologi dan sebagainnya. ${ }^{4}$

Di propinsi Jawa Barat pembuangan akhir tinja selain tanki sebanyak 45,03\% ke sungai atau danau, 29,81\% ke kolam, 19,55\% ke lubang tanah, ke pantai, kebun dan lain - lain sebanyak 3,02. Jika dilihat proporsi kabupaten/kota yang paling berkontribusi dalam hal tersebut, bentanganya hampir semua ada di Wilayah Jawa Barat bagian Selatan. Dan Kabupaten Majalengka tahun 2012 terdapat sumur gali (SGL) sebanyak 82,418 sarana $(44,89 \%) .^{5}$

Kabupaten Majalengka terdiri dari 31 Puskesmas dan salah satunya Puskesmas Kasokandel, berdasarkan data Puskesmas dari sepuluh desa di Wilayah Kerja UPTD Kasokandel desaLleuwikidang yang lebih rendah jumlah kepemilikan jamban keluarga di lihat pada tahun 2013 jumlah penduduknya 1.322 KK dengan jumlah rumah yang ada 1.214 yang sudah mengakses jamban 419 rumah (34,39\%) kebanyakan masih buang air besar ke sungai atau ke kebun, dari jumlah data yang ada bahwa desaLleuwikidang masih sangat rendah jumlah presentase yang sudah memiliki jamban keluarga dibandingkan dengan desa terdekat lainnya, di antaranya Desa Kasokandel yang telah mencapai 93,07, Jati sawit telah mencapai 63,9\%, Gandasari telah mencapi 91,40\%, dan Jatimulya telah mecapai 94,61\%. ${ }^{6}$

Dari hasil kajian diatas, terlihat bahwa di Kabupaten Majalengka khususnya di Desa Leuwikidang Wilayah Kerja UPTD Puskesmas Kasokandel akses jamban masih rendah, hal ini diasumsikan karena status sosial ekonomi masyarakat yang terdiri dari ketersediaan sarana air bersih ketersediaan lahan, pedapatan dan tingkat pendidikan rendah. ${ }^{6}$

Tujuan penelitian ini untuk mengetahui faktor-faktor yang berhubungan dengan kepemilikan jamban keluarga di Desa Leuwikidang Wilayah Kerja UPTD Puskesmas Kasokandel Kabupaten Majalengka tahun 2014.

\section{METODE PENELITIAN}

Jenis penelitian ini adalah analitik dengan rancangan cross sectional. ${ }^{7}$ Dalam penelitian ini variabel bebasnya adalah tingkat pendidikan, pekerjaan, tingkat pendapatan, kepemilikan sarana air bersih, dan kepemilikan lahan sedangkan variabel terikatnya adalah kepemilikan jamban keluarga. Populasi dalam penelitian ini adalah seluruh rumah yang berada di Desa Leuwikidang Wilayah Kerja UPTD Puskesmas Kasokandel dari 1214 Rumah. Pengambilan besar sampel menggunakan rumus Taro yamane. Besar sampel berdasarkan rumus pengambilan besar sampel didapatkan sebanyak 92 rumah. Jadi responden dalam penelitian ini adalah Kepala Keluarga sebanyak 92 Rumah yang terpilih sebagai sampel di Desa Leuwikidang Wilayah Kerja UPTD Kasokandel Kabupaten Majalengka tahun 2014.

Dari jumlah sampel 92 responden tersebut kemudian ditentukan jumlah masing masing sampel menurut Rukun Warga (RW) yang berada di Desa Leuwikidang secara Proporsional random sampling Untuk menentukan rumah pada masing-masing RW yang akan dijadikan sampel yaitu dengan menggunakan undian (lottrery technique)

Instrumen penelitian ini mengunakan kuesioner. ${ }^{7}$ Kuesioner diadopsi dari pemilik data skripsi Herdiana dengan judul "Faktor-faktor yang mempengaruhi kepemilikan jamban keluarga di Desa Situsari Kecamatan Darma Kabupaten Kuningan Tahun 2010"

Pengumpulan data primer dilakukan dengan wawancara secara langsung kepada responden dan observasi terhadap kepemilikan jamban keluarga, ketersediaan air bersih, dan kepemilikan lahan untuk membangun jamban, sedangkan untuk tingkat pendapatan, pekerjaan dan tingkat pendidikan dengan wawancara dan kuesioner. Data sekunder diperoleh dari instansi kesehatan yang bersangkutan yaitu hasil rekapan Puskesmas, dan monografi yang dapat dilihat dari kantor Desa. 
Analisis data dengan univariat dan bivariat. Univariat dimaksudkan untuk mendeskripsikan setiap variabel bebas dan variabel terikat dengan menggunakan tabel frekuensi. Sedangkan analisis bivariat digunakan untuk menguji hubungan antara variabelvariabel tersebut digunakan analisis statistik dengan uji chi square. Dasar pengambilan hipotesis penelitian berdasarkan tingkat signifikansi (nilai p), yaitu :

1. Jika $\mathrm{p} \leq 0,05$ maka Hipotesis penelitian (Ho) ditolak.

2. Jika $\mathrm{p}>0,05$ maka Hipotesis Penelitian (Ho) diterima.

\section{HASIL PENELITIAN}

\section{Kepemilikan Jamban Keluarga}

Berdasarkan hasil penelitian didapatkan bahwa rumah yang memiliki jamban keluarga sebanyak 36 rumah $(39,1 \%)$ dan yang tidak memiliki jamban keluarga sebanyak 56 rumah $(60,9 \%)$ di Desa Leuwikidang Wilayah Kerja UPTD Puskesmas Kasokandel Kabupaten Majalengka Tahun 2014.

\section{Pendidikan}

Berdasarkan hasil penelitian didapatkan bahwa kepala keluarga yang berpendidikan tinggi sebanyak 55 orang (59.8\%) dan kepala keluarga yang berpendidikan rendah sebanyak 37 orang $(40,2 \%)$ di Desa Leuwikidang Wilayah Kerja UPTD Puskesmas Kasokandel Kabupaten Majalengka Tahun 2014.

\section{Pekerjaan}

Berdasarkan hasil penelitian didapatkan bahwa kepala keluarga yang memiliki pekerjaan tetap sebanyak 43 orang $(46,7 \%)$ dan kepala keluarga yang tidak memiliki pekerjaan tetap sebanyak 49 orang $(53,3 \%)$ di Desa Leuwikidang Wilayah Kerja UPTD Puskesmas Kasokandel Kabupaten Majalengka Tahun 2014.

\section{Pendapatan}

Berdasarkan hasil penelitian didapatkan bahwa keluarga dengan pendapatan < Rp.1.000.000,- sebanyak 54 orang $(58,7 \%)$ dan keluarga dengan pendapatan $\geq$ Rp.1.000.000,sebanyak 38 orang $(41,3 \%)$ di Desa Leuwikidang Wilayah Kerja UPTD Puskesmas Kasokandel Kabupaten Majalengka Tahun 2014.

\section{Sarana Air Bersih Keluarga}

Berdasarkan hasil penelitian didapatkan bahwa keluarga yang memiliki sarana air bersih sebanyak 31 orang $(33,7 \%)$ dan keluarga yang tidak memiliki sarana air bersih sebanyak 61 orang $(66,3 \%)$ di Desa Leuwikidang Wilayah Kerja UPTD Puskesmas Kasokandel Kabupaten Majalengka Tahun 2014.

\section{Kepemilikan Jamban Keluarga}

Berdasarkan hasil penelitian didapatkan bahwa keluarga yang memiliki lahan sebanyak 46 orang $(50,0 \%)$ dan keluarga yang tidak memiliki lahan sebanyak 46 orang $(50,0 \%)$ di Desa Leuwikidang Wilayah Kerja UPTD Puskesmas Kasokandel Kabupaten Majalengka Tahun 2014. 


\section{Hubungan Pendidikan Kepala Keluarga dengan Kepemilikan Jamban Keluarga}

Tabel 1 Hubungan Pendidikan Kepala Keluarga dengan Kepemilikan Jamban Keluarga

\begin{tabular}{|c|c|c|c|c|c|c|c|}
\hline \multirow{3}{*}{ Pendidikan } & \multicolumn{4}{|c|}{ Kepemilikan Jamban } & & & \multirow{3}{*}{ Pvalue } \\
\hline & \multicolumn{2}{|c|}{$\begin{array}{c}\text { Tidak } \\
\text { Memiliki }\end{array}$} & \multicolumn{2}{|c|}{ Memiliki } & & & \\
\hline & $\mathrm{n}$ & $\%$ & $\mathrm{n}$ & $\%$ & $\mathrm{n}$ & $\%$ & \\
\hline Rendah & 16 & 43.2 & 21 & 56.8 & 37 & 100 & \multirow{3}{*}{0,656} \\
\hline Tinggi & 20 & 36.4 & 35 & 63.6 & 55 & 100 & \\
\hline Total & 36 & 39.1 & 56 & 60.9 & 92 & 100 & \\
\hline
\end{tabular}

Berdasarkan tabel 1 dari 43 orang kepala keluarga dengan pendidikan tinggi terdapat 20 orang $(36,4 \%)$ yang memiliki jamban keluarga dan sebanyak 35 orang $(63,6 \%)$ yang tidak memiliki jamban keluarga, dan dari 37 kepala keluarga dengan pendidikan rendah terdapat 16 orang $(43,2 \%)$ memiliki jamban keluarga dan sebanyak 21 orang $(56,8 \%)$ tidak memiliki jamban keluarga.

Hasil uji statistik menggunakan uji chi square dengan $\alpha=0,05$ didapatkan nilai $\mathrm{p}=0,656$ $(\mathrm{p}>\alpha)$. Hal ini berarti $\mathrm{H}_{0}$ gagal ditolak yang berarti tidak ada hubungan pendidikan kepala keluarga dengan kepemilikan jamban

\section{Hubungan Pekerjaan Kepala Keluarga dengan Kepemilikan Jamban Keluarga}

Tabel 2 Hubungan Pekerjaan Kepala Keluarga dengan Kepemilikan Jamban Keluarga

\begin{tabular}{ccccccccc}
\hline & \multicolumn{3}{c}{ Kepemilikan Jamban } & & & \multirow{2}{*}{ P value } \\
\cline { 2 - 7 } Pekerjaan & \multicolumn{2}{c}{ Tidak } & \multicolumn{2}{c}{ Memiliki } & & & \\
& Memiliki & n & $\%$ & $\mathrm{n}$ & $\%$ & $\mathrm{n}$ & $\%$ & \\
\cline { 2 - 7 } & 21 & 42.9 & 28 & 57,1 & 49 & 100 & \\
\hline Tidak tetap & 15 & 34.9 & 28 & 65.1 & 43 & 100 & 0,570 \\
Tetap & 36 & 39.1 & 56 & 60.9 & 92 & 100 & \\
\hline Total & & & & &
\end{tabular}

Berdasarkan tabel 2 menunjukan bahwa dari 43 orang kepala keluarga dengan pekerjaan tetap terdapat 15 orang $(34,9 \%)$ yang memiliki jamban keluarga dan sebanyak 28 orang $(65,1 \%)$ yang tidak memiliki jamban keluarga. dan dari 49 kepala keluarga dengan pekerjaan tidak tetap terdapat 21 orang $(42,9 \%)$ memiliki jamban keluarga dan sebanyak 28 orang $(57,1 \%)$ tidak memiliki jamban keluarga.

Hasil uji statistik menggunakan uji chi square dengan $\alpha=0,05$ didapatkan nilai $\mathrm{p}=0,570(\mathrm{p}>\alpha)$. Hal ini berarti $\mathrm{H}_{0}$ gagal ditolak yang berarti tidak ada hubungan pekerjaan kepala keluarga dengan kepemilikan jamban keluarga. 


\section{Hubungan Pendapatan Keluarga dengan Kepemilikan Jamban Keluarga}

Tabel 3 Hubungan Pendapatan Keluarga dengan Kepemilikan Jamban Keluarga

\begin{tabular}{|c|c|c|c|c|c|c|c|}
\hline \multirow{3}{*}{ Pendapatan } & \multicolumn{4}{|c|}{ Kepemilikan Jamban } & \multirow[b]{3}{*}{$\mathrm{n}$} & \multirow[b]{3}{*}{$\%$} & \multirow{3}{*}{ Pvalue } \\
\hline & \multicolumn{2}{|c|}{$\begin{array}{c}\text { Tidak } \\
\text { Memiliki }\end{array}$} & \multicolumn{2}{|c|}{ Memiliki } & & & \\
\hline & $\mathrm{n}$ & $\%$ & $\mathrm{n}$ & $\%$ & & & \\
\hline$\geq$ Rp. 1000.000,- & 12 & 31.6 & 26 & 68.4 & 38 & 100 & \multirow{3}{*}{0,304} \\
\hline \multirow[t]{2}{*}{ < Rp. 1.000.000,- } & 24 & 44.4 & 30 & 55.6 & 54 & 100 & \\
\hline & 36 & 39.1 & 56 & 60.9 & 92 & 100 & \\
\hline
\end{tabular}

Berdasarkan tabel 3 menunjukkan bahwa dari 54 orang kepala keluarga dengan pendpatan $<$ Rp.1.000.000,- terdapat 24 orang $(44,4 \%)$ yang memiliki jamban keluarga dan 30 orang $(55,6 \%)$ yang tidak memiliki jamban keluarga. dan dari 38 kepala keluarga dengan pendapatan $\geq$ Rp.1.000.000,- terdapat 12 orang $(31,6 \%)$ memiliki jamban keluarga dan sebanyak 26 orang $(68,4 \%)$ tidak memiliki jamban keluarga.

Hasil uji statistik menggunakan uji chi square dengan $\alpha=0,05$ didapatkan nilai $\mathrm{p}=0,304(\mathrm{p}>\alpha)$. Hal ini berarti $\mathrm{H}_{0}$ gagal ditolak yang berarti tidak ada hubungan pendapatan keluarga dengan kepemilikan jamban keluarga.

\section{Hubungan Sarana Air Bersih dengan Kepemilikan Jamban Keluarga.}

Tabel 4 Hubungan Sarana Air Bersih dengan Kepemilikan Jamban Keluarga.

\begin{tabular}{ccccccccc}
\hline & \multicolumn{3}{c}{ Kepemilikan Jamban } & & & \multirow{2}{*}{ P value } \\
\cline { 2 - 7 } Sarana Air Bersih & \multicolumn{2}{c}{ Tidak } & \multicolumn{2}{c}{ Memiliki } & & & \\
& Memiliki & & & & & \\
& $\mathrm{n}$ & $\%$ & $\mathrm{n}$ & $\%$ & $\mathrm{n}$ & $\%$ & \\
\cline { 2 - 7 } Tidak Memiliki & 19 & 31.1 & 42 & 68.9 & 61 & 100 & \\
Memiliki & 17 & 54.8 & 14 & 45.2 & 31 & 100 & 0,048 \\
\hline Total & 36 & 39.1 & 56 & 60.9 & 92 & 100 & \\
\hline
\end{tabular}

Berdasarkan tabel 4 menunjukkan bahwa dari 31 keluarga yang memiliki sarana air bersih terdapat 17 orang $(54,8 \%)$ yang memiliki jamban keluarga dan sebanyak 14 orang $(45,2 \%)$ yang tidak memiliki jamban keluarga. dan dari 61 keluarga yang memiliki sarana air bersih terdapat 19 orang $(31,1 \%)$ memiliki jamban keluarga dan sebanyak 42 orang $(68,9 \%)$ tidak memiliki jamban keluarga.

Hasil uji statistik menggunakan uji chi square dengan $\alpha=0,05$ didapatkan nilai $\mathrm{p}=0,048$ $(\mathrm{p}>\alpha)$. Hal ini berarti $\mathrm{H}_{0}$ ditolak yang berarti ada hubungan sarana air bersih dengan kepemilikan jamban keluarga 


\section{Hubungan Kepemilikan Lahan dengan Kepemilikan Jamban Keluarga}

Tabel 5 Hubungan Kepemilikan Lahan dengan Kepemilikan Jamban Keluarga

\begin{tabular}{|c|c|c|c|c|c|c|c|}
\hline \multirow{3}{*}{ Kepemilikan Lahan } & \multicolumn{4}{|c|}{ Kepemilikan Jamban } & & & \multirow{3}{*}{ Pvalue } \\
\hline & \multicolumn{2}{|c|}{$\begin{array}{c}\text { Tidak } \\
\text { Memiliki }\end{array}$} & \multicolumn{2}{|c|}{ Memiliki } & & & \\
\hline & $\mathrm{n}$ & $\%$ & $\mathrm{n}$ & $\%$ & $\mathrm{n}$ & $\%$ & \\
\hline Tidak Memiliki lahan & 20 & 43.5 & 26 & 56.5 & 46 & 100 & \multirow{3}{*}{0,522} \\
\hline Memiliki lahan & 16 & 34.8 & 30 & 65.2 & 46 & 100 & \\
\hline Total & 36 & 39.1 & 56 & 60.9 & 92 & 100 & \\
\hline
\end{tabular}

Berdasarkan tabel 5 dari 46 keluarga yang memiliki lahan terdapat 16 orang $(34,8 \%)$ yang memiliki jamban keluarga dan sebanyak 30 orang $(65,2 \%)$ yang tidak memiliki jamban keluarga dan dari 46 keluarga yang memiliki lahan terdapat 20 orang $(43,5 \%)$ memiliki jamban keluarga dan sebanyak 26 orang $(56,5 \%)$ tidak memiliki jamban keluarga.

Hasil uji statistik menggunakan uji chi square dengan $\alpha=0,05$ didapatkan nilai $\mathrm{p}=0,522$ $(\mathrm{p}>\alpha)$. Hal ini berarti $\mathrm{H}_{0}$ gagal ditolak yang berarti tidak ada hubungan kepemilikan lahan dengan kepemilikan jamban keluarga di Desa Leuwikidang Wilayah Kerja UPTD Puskesmas Kasokandel Kabupaten Majalengka tahun 2014.

\section{PEMBAHASAN}

\section{Hubungan Pendidikan Kepala Keluarga dengan Kepemilikan Jamban Keluarga}

Berdasarkan hasil penelitian menunjukan hasil uji chi square dengan $\alpha=0,05$ didapatkan nilai $p=0,656(p>\alpha)$ yang berarti tidak ada hubungan pendidikan kepala keluarga dengan kepemilikan jamban keluarga di Desa Leuwikidang Wilayah Kerja UPTD Kasokandel Kabupaten Majalengka tahun 2014.

Tingkat pendidikan berhubungan dengan kemampuan menerima informasi kesehatan dari media massa dan petugas kesehatan. Tingkat pendidikan dapat berkaitan dengan kemampuan menyerap dan menerima informasi kesehatan serta kemampuan dalam berperan serta dalam pembangunan kesehatan. Masyarakat yang memiliki tingkat pendidikan yang lebih tinggi pada umumnya mempunyai wawasan luas sehingga lebih mudah menyerap danmenerima informasi, serta dapat ikut berperan serta aktif dalam mengatasi masalah kesehatan dirinya dan keluarganya. ${ }^{8}$

Penelitian ini tidak sejalan dari penelitian yang telah dilakukan oleh Herman Junaedi tahun 2002, dan penelitian ini juga tidak sejalan dengan Hardinia Endrawati tahun 2008. Karena hasil penelitian yang dilakukan di desa Leuwikidang Kecamatan Kasokandel bahwa pendidikan tidak mempengaruhi faktor hubungan dengan kepemilikan jamban karena kurang nya kesadaran atau kemauan untuk memiliki jamban keluarga. ${ }^{8}$

\section{Hubungan Pekerjaan Kepala Keluarga dengan Kepemilikan Jamban Keluarga}

Berdasarkan hasil menunjukan hasil uji chi square dengan $\alpha=0,05$ didapatkan nilai $\mathrm{p}=0,570(\mathrm{p}>\alpha)$ yang berarti tidak ada hubungan pekerjaan kepala keluarga dengan kepemilikan jamban keluarga di Desa Leuwikidang Wilayah Kerja UPTD Puskesmas Kasokandel Kabupaten Majalengka tahun 2014.

Karakteristik pekerjaan seseorang dapat mencerminkan pendapatan, status sosial, pendidikan, status sosial ekonomi, risiko cedera atau masalah kesehatan dalam suatu kelompok populasi. Pekerjaan juga merupakan suatu determiner risiko dan determiner 
terpapar yang khusus dalam bidang pekerjaan tertentu serta merupakan prediktor status kesehatan dan kondisi tempat suatu populasi bekerja. ${ }^{9}$

Penelitian ini tidak sejalan dari penelitian yang telah dilakukan oleh Sulistyorini tahun 2008 ,dan penelitian ini juga tidak sejalan dengan Hardinia Endrawati tahun 2008. Karena hasil penelitian yang dilakukan di desa Leuwikidang Kecamatan Kasokandel bahwa pekerjaan tidak mempengaruhi faktor hubungan dengan kepemilikan jamban karena kurang nya kesadaran atau kemauan untuk memilki jamban keluarga. ${ }^{8}$

\section{Hubungan Pendapatan Keluarga dengan Kepemilikan Jamban Keluarga}

Berdasarkan hasil penelitian menunjukan hasil uji chi square dengan $\alpha=0,05$ didapatkan nilai $\mathrm{p}=0,304(\mathrm{p}>\alpha)$ yang berarti tidak ada hubungan pendapatan keluarga dengan kepemilikan jamban keluarga di Desa Leuwikidang Wilayah Kerja UPTD Puskesmas Kasokandel Kabupaten Majalengka tahun 2014.

Tingkat pendapatan berkaitan dengan kemiskinan yang akan berpengaruh pada status kesehatan masyarakat. Faktor-faktor lain yang mempengaruhi antara lain adalah jenis pekerjaan, pendidikan formal kepala keluarga, jumlah anggota keluarga dan lain-lain.

Penelitian ini tidak sejalan dengan penelitian Hardinia Endrawati tahun 2008. Karena hasil penelitian yang dilakukan di desa Leuwikidang Kecamatan Kasokandel bahwa pendapatan tidak mempengaruhi faktor hubungan dengan kepemilikan jamban karena kurang nya kesadaran atau kemauan untuk memiliki jamban keluarga. ${ }^{8}$

\section{Hubungan Sarana Air Bersih dengan Kepemilikan Jamban Keluarga}

Berdasarkan hasil penelitian menunjukan hasil uji chi square dengan $\alpha=0,05$ didapatkan nilai $\mathrm{p}=0,048(\mathrm{p}<\alpha)$ yang berarti ada hubungan sarana air bersih dengan kepemilikan jamban keluarga di Desa Leuwikidang Wilayah Kerja UPTD Puskesmas Kasokandel Kabupaten Majalengka tahun 2014.

Penelitian ini sejalan dari penelitian yang telah di lakukan oleh Herman Junaedi tahun 2002, dan penelitian ini juga sejalan dengan Hardinia Endrawati tahun 2008. Karena hasil penelitian yang dilakukan di desa Leuwikidang Kecamatan Kasokandel bahwa sarana air bersih dapat mempengruhi faktor hubungan dengan kepemilikan jamban keluarga dikarenakan masih terbatasnya sumber air bersih hingga kurang efisien untuk menggunakan jamban keluarga. ${ }^{8}$

\section{Hubungan Kepemilikan Lahan dengan Kepemilikan Jamban Keluarga}

Berdasarkan hasil penelitian menunjukan hasil uji chi square dengan $\alpha=0,05$ didapatkan nilai $\mathrm{p}=0,522(\mathrm{p}>\alpha)$ yang berarti tidak ada hubungan kepemilikan lahan dengan kepemilikan jamban keluarga di Desa Leuwikidang Wilayah Kerja UPTD Puskesmas Kasokandel Kabupaten Majalengka tahun 2014.

Kepemilikan jamban keluarga sangat berkaitan dengan ketersediaan lahan untuk bangunan jamban. Pada pemukiman padat penduduk lahan sangat terbatas terutama untuk bangunan penampung kotoran, semakin sempit lahan pemukiman semakin jarang jamban yang tersedia. Dari aspek sosial ekonomi, daya beli masyarakat masih di prioritaskan kepada pemenuhan dasar lain sehinggawalaupun memahami pentingnya jamban tetapi belum bisa membangunnya karena alasan tidak ada dana.

Penelitian ini tidak sejalan dari penelitian yang telah dilakukan oleh Herlianto tahun 2006, dan penelitian ini juga tidak sejalan dengan Sulistyorini tahun 2008. Karena hasil penelitian yang dilakukan di desa Leuwikidang Kecamatan Kasokandel bahwa kepemilikan lahan tidak mempengaruhi faktor hubungan dengan kepemilikan jamban karena kurangnya kesadaran atau kemauan untuk memilki jamban keluarga. ${ }^{10}$ 


\section{SIMPULAN}

1. Tidak ada hubungan pendidikan kepala keluarga dengan kepemilikan jamban keluarga di Desa Leuwikidang Wilayah Kerja UPTD Puskesmas Kasokandel Kabupaten Majalengka tahun 2014.

2. Tidak ada hubungan pekerjaan kepala keluarga dengan kepemilikan jamban keluarga di Desa Leuwikidang Wilayah Kerja UPTD Puskesmas Kasokandel Kabupaten Majalengka tahun 2014.

3. Tidak ada hubungan pendapatan keluarga dengan kepemilikan jamban keluarga di Desa Leuwikidang Wilayah Kerja UPTD Puskesmas Kasokandel Kabupaten Majalengka tahun 2014.

4. Ada hubungan sarana air bersih dengan kepemilikan jamban keluarga di Desa Leuwikidang Wilayah Kerja UPTD Puskesmas Kasokandel Kabupaten Majalengka tahun 2014.

5. Tidak ada hubungan kepemilikan lahan dengan kepemilikan jamban keluarga di Desa Leuwikidang Wilayah Kerja UPTD Puskesmas Kasokandel Kabupaten Majalengka tahun 2014.

\section{SARAN}

\section{Dinas Kesehatan}

Pada pengelola program Kesehatan perlu strategi lain dalam merencanakan program penambahan sarana dan prasarana air bersih seperti dibantu oleh PNPM dan dilakukannya program PAMSIMAS.

\section{Bagi Puskesmas}

Untuk Wilayah Kerja UPTD Puskesmas Kasokandel :

1) Membuat usulan untuk pembuatan sarana air bersih melalui Dinas Kesehatan yang di bantu oleh biaya di dukung sikap pemerintah daerah secara nyata.

2) Puskesmas memberikan bantuan jamban keluarga pada masyarakat dengan membuat usulan pengadaan jamban keluarga melalui APBD.

3) Hendaknya petugas memberi binaan dan secara intensif memberi penyuluhan tentang penting nya jamban keluarga ke setiap desa yang ada di wlilayah puskesmas.

4) Memperkenalkan kepada masyarakat dengan metode CLTS (Community lead Total Sanitation) untuk membangun sarana jamban keluaga hingga masyarakat tidak adanya ketergantungan pihak luar karena prinsip utama yaitu tidak ada subsidi terhadap pembangunan infrastruktur.

5) Pembentukan dan pembinaan kader kesehatan lingkungan agar program kepemilikan jamban keluarga yang sehat bisa terealisasi.

6) Melakukan kerja sama lintas sektor antara puskermas dengan dinas pendidikan untuk menyelengarakan program kejar paket A dalam rangka perbaikan pendidikan masyarakat.

\section{Bagi Masyarakat}

1) Hendaknya masyarakat menggalakan gerakan menabung untuk menbangun jamban keluarga.

2) Masyarakat yang tidak dapat menyiapkan uang secara kontan bisa mengikuti arisan dan setiap anggotanya bergiliran mendapatkan nya melalui undian.

3) Bagi masyarakat yang tidak memilki untuk membangun jamban bisa dengan membangun sistem jamak di mana satu tempat penampungan kotoran (septik tank) bisa di gunakan oleh beberapa keluarga.

4) Bagi masyarakat yang tidak memiliki pekerjaan di sarankan agar membuka usuha sendiri (wiraswata) sehigga tingkat pendapatan meningkat. 


\section{DAFTAR PUSTAKA}

1. Pokja AMPL. Posisi MDGs/AMPL Posisi Indonesia dalam upaya pencapaian tujuan 7 target 10, [di akses tanggal 23 September 2014]. Di unduh dari posisi MDGs_AMPL. htm .

2. Dinkes Propinsi Jawa Barat. Berkaca pada cermin sanitasi Jawa Barat.[di akses tanggal 25 September 2014]. Di unduh dari:http://www.dinkesjabar.go.id.

3. Kementrian Pekerjaan Umum. Pemerintah kucurkan dana Alokasi khusus (DAK) sanitasi Rp 375 milyar pada 2010.[di akses tanggal 25 September 2014]. Di unduh dari indeks php sanitasi pu, htm.

4. Gadjah Mada University Press. Epidemologi lingkungan, cetakan ke II, Yogyakarta: Gadjah mada University Press; 2005.

5. Dinkes Kabupaten Majalengka. Profil dinas kesehatan kabupaten Majalengka 2012 Artikel jamban keluarga. Informasi kesehatan untuk anda, 2009, [di akses tanggal 25 September 2014]. Di unduh dari Abahjack.com.

6. Puskesmas Kasokandel, Profil puskesmas kasokandel 2010: Kabupaten Majalengka; 2013.

7. Kantor Desa Situsari, Data monografi desa 2009: Darma kabupaten Majalengka; 2010

8. Herdiana Endrawati. Hubungan tingkatan pendidikan dengan pengetahuan serta pendapatan dengan kepemilikan jamban keluarga di Bloto Kecamatan Prajurit Kulon Kota Mojokerto tahun 2005.Skripsi: Mojokerto; 2005

9. Herlianto. Faktor-faktor yang berhubungan dengan kepemilikan jamban keluarga di Desa di Wilayah kerja Puskesmas Palak Bengkerung Kabupaten Bengkulu Selatan 2006. Skripsi: Bengkulu; 2006

10. Depkes RI. Pendapatan dengan kesehatan 2009. [di akses tanggal 2 Oktober 2014]. Di unduh dari: www.depkes.go.id 